\title{
The peculiar pose of Jessica Lynch Andrew Panay
}

This is an Accepted Manuscript of a book chapter published by Routledge in Barthes' mythologies today: readings of contemporary cutlure on June 2013

available online:

https://www.routledge.com/Barthes-Mythologies-

Today-Readings-of-Contemporary-Culture/BennettMcDougall/p/book/9780415821223 


\section{The Peculiar Pose of Jessica Lynch}

What are we now to make of the peculiar pose of Jessica Lynch? She appeared, as Paul Weller once sang, smiling beguiling on the April cover of Newsweek in 2003 framed by a star spangled banner. It is the smile of a youth, albeit one wearing the green fatigues of combat, and it is clear, some clarity of focus in her gaze unclouded towards the camera makes it clear, that as yet she has seen no combat, witnessed no deaths of her comrades; has not yet seen the face of the enemy. This is a photograph before experience and it resembles nothing so much as the graduation pose for one of those American high school year books. Indeed Jessica was once acclaimed by her classmates, as though from a bygone era, Miss Congeniality. It is certain that somewhere in the annals of some municipal high school in a poor white district of West Virginia where she comes from is a very similar photograph of a high school leaver. Miss Congeniality, of pleasant disposition, sympathetic, agreeable; her classmates were onto something! These self same qualities recognised by her peers and motivated who knows by genuine affection, though perhaps just as easily by the absence of anything in particular to say about this essentially unremarkable person, are all qualities no doubt recognised by the US military's Public Relations corps when they approved this photograph for publication and concocted her story. The editor's of Newsweek, that most congenial of American imperialist publications, surely understood immediately the impact that the juxtaposition of this photograph on its 
front cover would make alongside the haunting images and harrowing account of the soldier Jessica Lynch's violent assault, her abduction and the fevered speculations of her subsequent captivity.

Newsweek's front cover of Lynch in military garb is an extended high school graduation photograph, all youthful optimism and soft focus, bursting with potential. It contrasts strikingly with the account given inside of the desperate fire fight following an ambush of her US armoured column in Nasiriyah, Iraq. Lynch is described as resisting heroically whilst her comrades lie wounded and dying all around her, before she is herself finally subdued, her weapon runs out of ammunition, and is then dragged away amid the screaming cries of triumph of her enemies into captivity, to await her fate; rescue or death. Lynch is a female soldier of course, so the camera treats her lovingly. By contrast a man would appear stern, emotionless, wearing his war mask. He is a combat soldier, a trained killer. But Jessica Lynch? Not so with this Private. Her Newsweek pose presents a pretty, fair haired white woman in combat greens that look just a little too big for her, suggesting a vulnerability that seems deliberately staged and is almost coquettish, is coquettish in ways that are just a touch unsettling. She is proclaimed as everyone's daughter, sister and sweetheart. Even her humble country origins mark her out as an all American girl, the girl next door of folksy Americana. Jessica Lynch inspires by her captivity in some dark foreign cell an orgy of communal patriotism at home. Preachers of the fire and brimstone variety loudly condemn the works of Satan and Islam both, whilst others moved to sudden remembrance take to tying yellow ribbons around trees and lampposts and anything else that will serve just as well, the helpless rituals of previous wars. Still others attend candle light vigils, prayers for her safe return, 
outdoors affairs of solemn intensity in small rural towns where every building appears to be constructed of slender wooden planks that are painted a kind of cracked and faded white.

Two impressions of Lynch are apparent simultaneously reading Newsweek, innocence and heroism. In the American imaginary these are not unaligned but in fact historical correlates, something that no European surveying the ragged lines of their own national formation would any longer dare to venture or suggest. Jessica Lynch, her innocence and heroism, the patriotic coming together of determinedly ordinary folk that this inspires in small town America, represents everything that is superior about America over its enemies of the East, apparently a complex of territories and peoples having no real differentiation or certain location except whether they are for or against, welcoming or hostile to US military aggression. More than this though, and something which may provoke in foreigners only bewilderment or incredulity by degrees, Newsweek seems to say that as an American woman in what was once universally accepted as an entirely masculine arena, that of combat and the business of killing and being killed; Lynch above all else represents the superior values of western civilisation, and of the United States specifically, through determined progress towards woman's liberation. Here once again barely noticeable which is exactly how it is meant to be, is evidence of the works of that damnable industry began by Bernays, which is now inserted into the consciousness and activities of almost the entire planet, including theatres of global warfare. Newsweek asserts that the liberation of American women evidenced by the innocent and heroic soldier Jessica Lynch stands in positive contradistinction with what is known by us of the status and position of Muslim women of the dismal Middle East. In the west, we 
assert, our women enter the theatre of war alongside our men as equals, to kill and be killed. This is surely a peculiar kind of progress, and a strange sort of liberation.

Historically the relationship of women to war is lot less heroic sounding than this though. Woman have always occupied a strange and uncertain position in relation to their own potential for aggression and violence since this has been rarely their own to assert but rather been ascribed to them. What we find from the records is that where women are concerned it is not violence or aggression that defines them in war but rather passivity and, ahh yes, innocence. Women do not so much enter combat but provide meaning for it for others, for men. This is the western way of women at war, as facilitating the aggressive energies of men. Woman are fought over but do not fight, they provide a necessity for male aggression and violence since, somewhat ironically, they themselves are incapable of it. Women stand with the children in this regard. Men fight, at least honourable men fight, to protect woman and children, shield and shelter them. Why? Because innocence and passivity must be defended at all costs from the violence of men, other men, 'them', that historically fluid and contingent enemy. We must do this cosmic work even at the cost to our own humanity since the consequences of failure to do so are catastrophic, unthinkable, and will lead, so we are convinced, to civilisational ruin and collapse. This is why men must fight. Doing this work is what we mean in the west by heroic.

So, in narratives of warfare that define for us the historical record, the most visible role occupied by women during frequent periods of violent conflict is as victims, necessitating the kind of protection which we are convinced is only able to be provided through that special quality of masculinity, the propensity for deadly 
violence. The lot of woman in war is not heroism but suffering, this seems to be the best they can hope for. Even the character of women's victimhood is specific, defined by particular focus and attention on the body. Though there may be found some record of it women are typically excluded as violent combatants and are therefore denied the glorification that comes with injury or death sustained in armed combat, but they are prominent as the helpless recipients of violent sexual conquest, rape by the enemy, and they frequently suffer other tortures, witness the deaths of their children, grieve for the absence and sufferings of men and experience bodily dislocation and physical confinement through forced captivity, as Jessica Lynch does. Indeed, in American culture it is captivity that provides the drama for an entire genre that defines from its very first settlements in that part of the continent named by them New England to that part of the Middle East proclaimed by their 43rd president The New Iraq, the experience of women in time of war. It is a genre fixated on women's victimhood defining them in relation to the depredations of the enemy, both realised and potential, and to the heroism that defines American masculinity.

If we return once again to Newsweek, the story it tells of Jessica Lynch is filtered through a number of salient discourses, gender, race, though less prominently class; but the narrative it constructs is woven through generic tropes that relate the suffering of women's captivity in war with the collective experience of trauma experienced during conflict. Lynch's captivity so described is felt by the entire nation who come together and offer prayers for her release, and upon whose redemption ultimately resides the redemption of all. The earliest captivity tales, autobiographies of abduction by Indians closely supervised and ultimately penned by powerful men of stern religious intolerance, accounted for this by divine intervention, so that captivity and 
then release from this bondage was understood as a consequence of the quality of faith in God. Since the individual woman captive represented the entire community the quality of this faith was adjudged to be measured against not just her own conscience, but against the conscience of the entire social body. Captivity by Indian 'others', the godless savages lurking in the forests or waiting unseen in the vast open spaces of the great plains and parched deserts, became through centuries of bloody struggle for territorial supremacy a prime definer of the experience of being American. Each release from the clutches of the enemy strengthens and affirms the progress of the entire community whilst each death traumatises and reduces it. The entire narrative drama is decided by its outcome and its outcome becomes the entire meaning of the narrative as it unfolds. The fate of the captive, so entwined with the fate of her community, becomes a cosmic drama of them versus us, progress versus stagnation, civilisation versus savagery, and good versus evil.

Jessica Lynch resumes the historical trope of women's captivity in Newsweek, becoming a modern marker of the myth of community regeneration through trial by captivity, violence and blood. This is the meaning of Newsweek's front cover photograph of her, the juxtaposition of this with the accompanying narrative inside of violent assault, heroic resistance succumbing only at the last to capture and captivity, and speculation of brutal trial and sexual torture at the hands of savage captors. Ultimately, as the captivity narrative dictates, Lynch must be redeemed. A captivity story like this always exists with its potential on an uncertain plane, between myth and the mundane. If for example the captive dies whilst she is incarcerated, or is merely released in return for a cash ransom or through some shoddy backdoor political transaction, this will not satisfy the requirements of myth. Since the historical 
resolution of the captive drama hinges on the ability of the community to reaffirm itself, such an outcome substituting the role of the community for the calculating strategies of private individuals, politicians and diplomats, is diminished by comparison and succeeds in generating only indifference, or angry cynicism. To succeed as myth the community must first feel that there is something at stake for it to lose, something so fundamental to its wellbeing and security that loss will be catastrophic. Thus Jessica Lynch is presented as an everywoman, potentially our sister, our daughter, our sweetheart. In her occupation, in her role as soldier she serves and represents us, doing the necessary but brutal work to ensure the future of the community. Except she doesn't, not really, because at the same time Newsweek cannot forget that she is a woman and therefore also an innocent, not a proper combatant, far from the safety and security of home, and now in perilous existence deep in the domain of the infidel enemy.

Newsweek constructs its characterisation of Jessica Lynch and a narrative of individual and community peril that is mythic in its structure. It requires, for final fulfilment of its function as myth a resolution that satisfies the requirements of the community that it reaffirm the community entire; its legitimacy, its values and certainties, its mission and its destiny. The earliest captivities succeeded in this by reaffirming individual and community faith in God. So, when the captive was finally released, redeemed, this was understood to be by His grace, and served specific ideological and social functions, shoring up community obedience to pious religious orders, and strengthening the rule of the Divines. As theocratic control later receded to be replaced by secular order and national identity, so the meaning of the redeemed captive underwent alteration also, divine providence was substituted for earthly 
vengeance and patriotic fulfilment. The captive's faith in her eventual redemption through rescue shifted from that of God's will, to the skill (and impeccable timing) of the United States Cavalry. In modern times, and in the case of Jessica Lynch, redemption and rescue comes in the form of the hyper masculine US Special Forces.

In a famous film western of the 1960's, The Man Who Shot Liberty Valence, a newspaperman is heard to remark towards the dénouement of that picture that "when legend becomes fact, print the legend!' Newsweek printed the legend of Jessica Lynch's terrible experiences in Nasiriyah and her subsequent rescue. It framed her at the outset as a woman soldier supposedly the equal of her male colleagues, explanatory of the superiority of progressive western American values and ideals, whilst unable to reflect on the hideous imperialism buried within this proposition. Of Jessica Lynch the soldier, does she in fact transcend centuries of narrative descriptions of her vulnerability, innocence and passivity to become liberated by her own violent action, which is historically the narrative prerogative of men? Well no, and this part of the fabrication is soon allowed to slide as the real intention of the Lynch story, the perceived brutality of her captivity and the masculine courage of her patriotic rescue, takes over. No sooner does Newsweek, and indeed the entire American and much of the rest of the western media, the running dogs of global imperialism present the prospect of the liberated female warrior than it worries about her sexual vulnerability and is titillated by the images it conjures up for the anger of their consumers, outraged by thoughts of hyper-sexualised Iraqi men.

As with the historical women's captivity tale concern becomes fixated on the female body. Lynch's prettiness is commented upon and described, the girl next door quality 
of it, her diminutive physical stature is agonised over and her wounded state becomes a speculative theme, her vulnerability is examined, fetishised. Women, including soldiers like Lynch, are constructed as needing protection by men, from rape, from their own sexuality, from their femininity. Lynch's role in the military was not, in actual fact that of a front line soldier. She was not expected or meant by her country to fight. Her role, and the role of all US woman personnel, was as support, Lynch was a 'camp follower.' Though she was famously described as having been shot and wounded by the enemy prior to her capture it turns out her wounds resulted from automobile collision during the initial ambush. Of fears of sexual assault and amid charges of rape by Iraqis these were not recalled by Lynch herself or ever medically confirmed. Rape of US women military personnel though far more likely to come from within their own squads and platoons, was subsequently far less likely to receive media coverage.

At the time of her captivity the war in Iraq was not proceeding entirely as those conducting it in Washington or Darfur had intended. For a war so carefully prepackaged, so PR-ised, by this point in its presentation there was a distinct danger of the whole artifice unravelling. It was not only that there continued to be confusion, obfuscation and lies surrounding the reasons for waging war in the first place, but that it was taking so damned long and proving so damned difficult to win it. Moderate Iraqis, sensible Iraqis, freedom and peace loving Iraqis were proving to be not quite so thick on the ground as the coalition had intended, and indeed like ingrate children were at this point sowing the seeds of a future armed rebellion. The avowed intention to 'win hearts and minds', so often remarked upon by coalition military spokespersons, was going spectacularly awry. 
At first sight then the story of an ambush of a US military column in Nasiriyah, subsequent fire fight resulting in the deaths of many American soldiers, and Private Jessica Lynch's violent abduction and captivity might seem unpromising material with which to launch a propaganda counter offensive. Yet such is the power of myth that it serves propaganda with little or any recourse to the historical quality of the thing it portrays, beyond that which is mediated through the modern military entertainment industry. Lynch's rescue, when it came after two weeks, was a stage managed event inside a hospital and had all the qualities of a Hollywood blockbuster, and just about as much realism. Not that this seemed to matter all that much even when the lie was quickly exposed. What was important above all else was that myth had been fulfilled. The captive innocent having survived her ordeal by maintaining her faith in her nation's values, its mission and its military was in the end redeemed because of this and returned home. Jessica Lynch returned to the US to an ecstatic reception, an outpouring of national patriotic celebration and was proclaimed a hero and accorded all spoils due to a modern American icon, audience with the nation's chat show hosts, appearances on daytime and primetime TV, a book deal so that she could 'tell her story in her own words', and that ultimate accolade of American popularity, a made for television movie. 'When legend becomes fact, print the legend!' Indeed. 
